\title{
Source Data Model of Integration Manufacturing Information System
}

\author{
Yongjun Feng \\ University of Science and Technology Liaoning,Liaoning,China \\ xfsword@163.com
}

Keywords: Manufacturing, information, integrated, source data, model

\begin{abstract}
Considering the processes of manufacturing enterprise design, plan, technology, manufacture and etc, it analyses the composition and interdependence of enterprise information system data in this paper. Emphasizing the technical and process section data, analyzing these data's source, attribute and outgoing. It creates an integral information system basic data model, obtains a system overlap model of these kinds of source data acquisition, provides a settle method for source data incomplete, inaccurate, and substandard of the manufacturing enterprise information system.
\end{abstract}

\section{Introduction}

The significant character of integrated information system is that it covers all the principal post and operation flow, creates a complete business closed loop where there is not information isolated region exist. The traditional pattern's management focal points are fund and property, integrated finance and business, it exists some shortages such as plan function weak, source data incomplete, acquired inefficiency, information isolated region and a part of master business loop externally, which not only weakens the system value for enterprise ,but also is hard to use longtime and bruises the enterprise activeness. With the development of information age, more and more foreign system suppliers pay attention to these problems, begins to reconstruction the integrated information system where system source data model research has become an important content.

\section{Manufacturing enterprise basic business data and correlation analysis}

Manufacturing enterprise basic operation flow. Operation flow of the manufacturing enterprise is complex and it contains amount of information, so for a majority of the enterprises, they organize production following two ways, production by contract or contract containing pre-investment, which have became the key operation mode. For contract and market prediction all come from sales department, manufacturing order is the beginning of the whole production, following production preparation and delivery which form a main line business ring. That is to say, the main line management business of manufacturing enterprises is the flow process of the order material design, process, plan, implement and feedback information among different managerial posts and departments, see Fig1, which represents the enterprise management process macroscopically.

Business information correlation analysis. From the above analysis, it can find that when the enterprise internal order is fixed, the products are also settled, all the succeeding management information, the arrange fund and material flow develop around the products. Production design and process plan are to fix the scale of material requested, containing material kinds and norm which determine the material cost of the products and is the basis of purchase and external aiding plan, process route and man-hour norm which determine the productive cost and is the basis of fixing production plan. Key information and actions of the design and process are listed in table1.

From the above analysis, it finds that all the system basic information are order product design and technology, for the integral manufacture enterprise information system. These information not only layout the technology requirement of the product, but also layout the resource demand, which used to program different plans directly, driving cash flow, object flow and workflow to finish the product. From this view, different plans are to program the detailed layout of how to satisfy the product technology requirement and how to satisfy product resource demand, plan executing and controlling are the specific behavior, all of these come from the information generated from product design and process layout. 


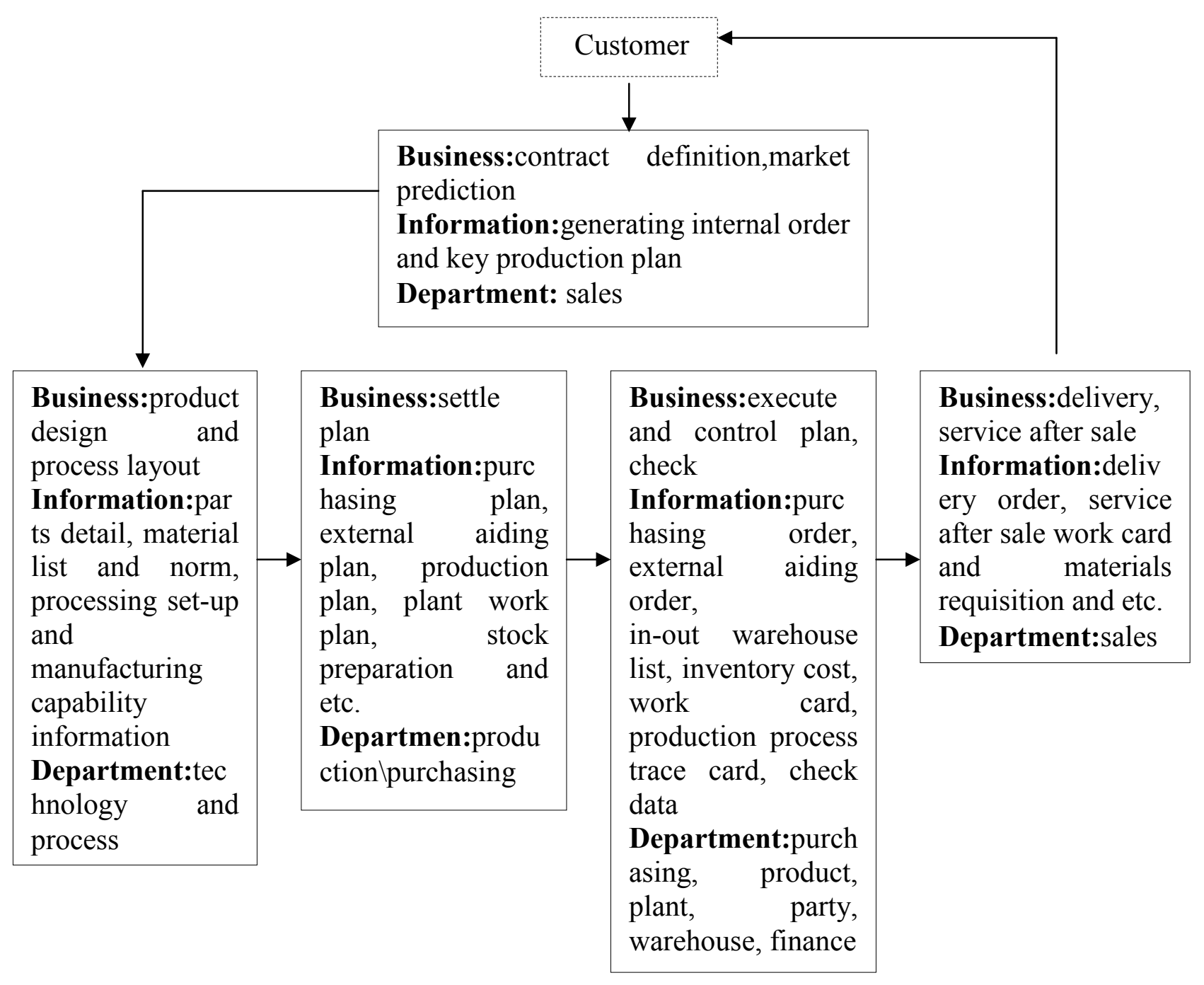

Fig. 1. Manufacturing enterprise basic operation flow and information flow

Table1 Key information and actions of the design and process

\begin{tabular}{|c|l|l|}
\hline Business & Information & \multicolumn{1}{c|}{ Information actions } \\
\hline \multirow{4}{*}{$\begin{array}{c}\text { Assemblage } \\
\text { design }\end{array}$} & $\begin{array}{l}\text { Drawing, } \\
\text { technology and } \\
\text { requirement, } \\
\text { Scale and } \\
\text { parts serial } \\
\text { number }\end{array}$ & $\begin{array}{l}\text { Drawing } \\
\text { number, } \\
\text { Norm and } \\
\text { technology requirement and etc. It is the foundation of discriminating } \\
\text { parts composition and assemblage requirement. Under current } \\
\text { technology, these information delivered by paper and is the main } \\
\text { contents of transition drawings business. }\end{array}$ \\
$\begin{array}{l}\text { in the } \\
\text { assemble } \\
\text { drawing detail } \\
\text { column }\end{array}$ & $\begin{array}{l}\text { Showing the assemble relationship of the product parts, manufacture' } \\
\text { attributes of corresponding part, products by itself, external aiding } \\
\text { products, standard parts and auxiliary equipment, which is the } \\
\text { foundation of forming product structure tree. }\end{array}$ \\
\cline { 2 - 4 } & $\begin{array}{l}\text { Assembled } \\
\text { equipment } \\
\text { name }\end{array}$ & $\begin{array}{l}\text { Showing the component name, which is a part of nodal point name } \\
\text { and product detail data components. }\end{array}$ \\
\hline
\end{tabular}




\begin{tabular}{|c|c|c|}
\hline & $\begin{array}{l}\text { Assembled } \\
\text { equipment } \\
\text { weight }\end{array}$ & $\begin{array}{l}\text { Showing the equipment global weight, which is a important } \\
\text { foundation of determine material norm and shop output value } \\
\text { checking. }\end{array}$ \\
\hline & $\begin{array}{l}\text { Other } \\
\text { information }\end{array}$ & The contents same as part drawing \\
\hline \multirow{5}{*}{ Part design } & $\begin{array}{l}\text { Drawing, } \\
\text { Diameters } \\
\text { and } \\
\text { technology } \\
\text { requirement, } \\
\text { Scales }\end{array}$ & $\begin{array}{l}\text { Showing the requirements of part structure, size, manufacture and } \\
\text { check requirements, it is the foundation of identifying parts for } \\
\text { technical personnel. Under current technology, these information } \\
\text { delivered by paper and is the main contents of transition drawings } \\
\text { business. }\end{array}$ \\
\hline & Name & $\begin{array}{l}\text { Showing the name of the part, it is the one of components of product } \\
\text { structure tree. }\end{array}$ \\
\hline & Drawing size & $\begin{array}{l}\text { Reflected directly in detail columns of assemble drawing, it is the } \\
\text { main foundation of forming the product structure tree. }\end{array}$ \\
\hline & Material & $\begin{array}{l}\text { Indicating the product material, it is the key basis of manufacture } \\
\text { process, using for fix the material detail, purchasing plan, send and } \\
\text { receiver material order, cost checking and etc. }\end{array}$ \\
\hline & Weight & $\begin{array}{l}\text { Showing the part design weight, it is the key data of fixing material } \\
\text { norm and output value checking. }\end{array}$ \\
\hline \multirow{10}{*}{$\begin{array}{l}\text { Process } \\
\text { route layout }\end{array}$} & Material & Showing the part material, it's action is same as above. \\
\hline & Material norm & $\begin{array}{l}\text { Showing the part material norm limitation, it is used for controlling } \\
\text { cost and scheduling purchase plan. }\end{array}$ \\
\hline & $\begin{array}{l}\text { Blanking } \\
\text { dimension }\end{array}$ & $\begin{array}{l}\text { Showing the blanking requirement, it is key references of scheduling } \\
\text { purchase plan, delivered to staff on process cards. }\end{array}$ \\
\hline & $\begin{array}{l}\text { Brocess } \\
\text { number }\end{array}$ & $\begin{array}{l}\text { Showing the manufacture precedence, it is the foundation of } \\
\text { scheduling workshop job time sequence. }\end{array}$ \\
\hline & Process name & $\begin{array}{l}\text { Showing the manufacturing method, it is the foundation of scheduling } \\
\text { job time sequence, manufacture party and section. }\end{array}$ \\
\hline & $\begin{array}{l}\text { Process } \\
\text { quirement }\end{array}$ & $\begin{array}{l}\text { Showing the technology requirement of some process manufacture } \\
\text { time, delivered to staff on paper. }\end{array}$ \\
\hline & Department & $\begin{array}{l}\text { Showing the finish department of some manufacture process, it is the } \\
\text { foundation of scheduling the job plan time and manufacture position. }\end{array}$ \\
\hline & $\begin{array}{l}\text { Manufacture } \\
\text { equipment }\end{array}$ & $\begin{array}{l}\text { Showing the manufacture equipment of one process, it is the } \\
\text { foundation of dividing equipment job. }\end{array}$ \\
\hline & $\begin{array}{l}\text { Knife tool and } \\
\text { accessory }\end{array}$ & $\begin{array}{l}\text { Showing the requirement of knife tool, accessory and etc during the } \\
\text { process, which determine the manufacture cost. }\end{array}$ \\
\hline & $\begin{array}{l}\text { Man-hour } \\
\text { norm }\end{array}$ & $\begin{array}{l}\text { Showing the process time requirement, it is the time foundation of } \\
\text { programming workshop job plan, determining the manufacture cost. }\end{array}$ \\
\hline
\end{tabular}

\section{Basis information model}

It has been determined from the above that product design information and process layout information are the source and foundation of plan and plan executing and controlling. This information flow format is the objective behavior of enterprise main line business management flow, it must to be a following law of manufacture enterprises integral information system. On this basis, information transition among different business flow should satisfy that product design and technology layout course must supply complete, accurate, standard and unique information in time for the sequence plan from design and process view firstly, secondly from plan layout view, which is an important labeling of integral information system. Under the current technology, some data in table 1 must to be delivered on paper providing convenience for workman, other information must flow timely, accurately, completely and standard in integral information system, then the source data model is got, shown in fig2. 


\begin{tabular}{|c|c|c|}
\hline \multirow{8}{*}{$\begin{array}{c}\text { Design } \\
\text { information }\end{array}$} & $\begin{array}{l}\text { drawing number, norm, material } \\
\text { kind in setting drawing detailed } \\
\text { columns }\end{array}$ & \multirow{4}{*}{ EBOM } \\
\hline & setting drawing number & \\
\hline & assembled equipment name & \\
\hline & assembled equipment weight & \\
\hline & part name & \\
\hline & part drawing number & \\
\hline & part material & \\
\hline & part weight & \\
\hline \multirow{9}{*}{$\begin{array}{l}\text { Technology } \\
\text { information }\end{array}$} & part material & \\
\hline & material norm & \\
\hline & blanking size & \\
\hline & process number & \multirow{6}{*}{ PBOM } \\
\hline & process name & \\
\hline & section & \\
\hline & manufacture equipment & \\
\hline & cuter and appurtenance & \\
\hline & man-hour quota & \\
\hline
\end{tabular}

Fig. 2. Integral manufacture enterprise information system source data model

\section{Integral information system source data acquisition mode}

For the finance and business integral information system, the function can not overlay product design and process layout, so the source data needed are got from building BOM concentrically where existing many deficiency such as it can not guarantee the information complete, in time and accurate, system function and enterprise post cannot match, working efficiency low and alter difficulty. While integral information system emphasizes cover the whole main line business flows, all the information come from unique source and match to enterprise post and function. So integral information system source data is accompany with design and technology, delivered to plan system after abstracted and summarized automatically.

Currently, CAD,CAPP,PDM(PLM) technology have matured, manage the CAD/CAPP data forward, integral highly with ERP backward, which can settle the problems existing in source data abstracting and delivering, shown in fig3.

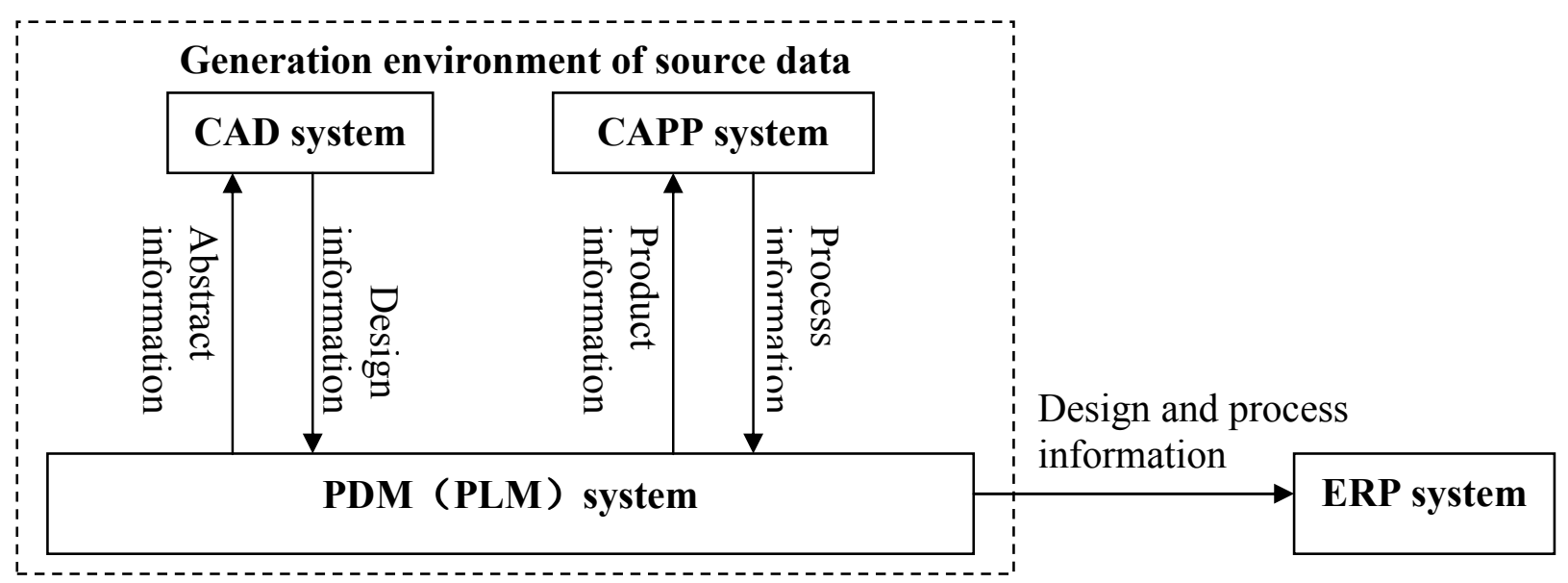

Fig. 3. Method of manufacture enterprise integral information system building and source data abstracting 


\section{Conclusion}

During the process of operating enterprise information strategy, integral main line system settle scheme covering all he main line business is the first choice comparing with domestic and foreign mature system. It can help enterprise prepare source data for integral information system timely, correctly, completely and uniquely. On the basis of the model, enterprise should analysis the system data and flow generally, coming form the management practice, integrate closely the CAD/CAPP and PDM(PLM)to create the source data system, then to integrate PDM(PLM)and ERP to realize delivering data automatically.

\section{References}

[1] WU Quanyuan ,SHI Dianxi. Information Systems and Their Comprehensive Integration Technologies,J. COMPU TER EN GINEERING \& SCIENCE.31(2009) 1-4.

[2] XIE Xihua,HE Qinghua,ZHOU Liang. Classif ication coding mode of PDM based on flexible structure,J. Computer Integrated Manufacturing Systems.11(2005)1683-1686.

[3] WANG Xiwei,QIU Jianxin,FAN Xiaochun. Information integration between PDM and ERP in distributed collaborative design,J. Journal of Jilin University ( Engineering and Technology Edition).33(2003)86-91.

[4] GOU Jihua,PENG Yinghong,RUAN Xueyu. Product Data Model in Product Data Management,J. JOURNAL OF SHANGHAI JIAO TONG UNIVERSITY.34(2000)404-407.

[5] HOU Shouming,DU Shouheng,LI Huifang. Research and Development of Integrated CAD/CAPP/PDM System for Minor Enterprise,J.Coal Engineering.7(2002)46-48.

[6] CAO Yang,NING Ruxin,ZUO Xin,et al. A Multi-Model Integrated CAPP System Based on PDM,J. Journal of Beijing Institute of Technology.22(2002)425-428.

[6] ZHENG Lemin,ZHANG Zongneng. Research About Basic Data Related to CRP and Problem Improvement for ERP Implementation,J. Computer Engineering,30(2004)434-436. 